\title{
The Effect of Black Coffee and Tea Consumption to Saliva Degree of Acidity in Preventing Tooth Decay
}

\author{
Erni Mardiati", Endah Aryati, Irmanita Wiradona, Bedjo Santoso \\ Poltekkes Kemenkes Semarang, Indonesia \\ *Corresponding Author: Erni Mardiati, Politeknik Kesehatan, Kemenkes Semarang, Jl. Tirto Agung \\ Pedalangan, Banyumanik, Indonesia.Email: erni.mardiati28@gmail.com
}

\begin{abstract}
Background: The degree of acidity $(\mathrm{pH})$ is one important factor that plays a role in the prevention of dental caries and tooth demineralization. Being most commonly consumed, black coffee as well as tea have antibacterial effects, so effective as anti-plaque and prevent decreasing $\mathrm{pH}$ saliva.

The Objective: This study aims to determine the effect before and after consumption of black coffee and black tea in determining the degree of acidity in saliva.
\end{abstract}

Method: The research was a quasi-experimental research with the cross-sectional approach. The design in this study used a pretest and posttest taken 40 respondents.

Result: The results showed that the saliva acid level $(\mathrm{pH})$ before the consumption of black coffee and black tea is different. The change in average salivary $\mathrm{pH}$ before and after consumption of black coffee was 0.4 and 0.3 for black tea.

Conclusion: The conclusion between black coffee and black tea consumption tends to affect the salivary of pH. Based on the results of the study, people are advised to consume black coffee and black tea a maximum of 2 cups in a day.

Keywords: Saliva pH, Black Coffee, Black Tea

\section{INTRODUCTION}

Dental caries is a disease of the hard tissues of the teeth caused by the activity of a microorganism characterized by the presence of demineralized tissue of hard tooth (Koerniati, 2006). The formation of dental caries is caused by various factors, including the presence of bacteria and lactobacilli Streptococcus mutants. Bacteria are the change of glucose and carbohydrates in the food into acids through fermentation. The acidity of saliva also affects the incidence of dental cavities or caries levels, salivary flow the easier the occurrence of caries (Pratiwi, 2007).

The degree of acidity $(\mathrm{pH})$ is one of the important factors that play a role in the prevention of dental caries and tooth demineralization (Imran, 2016). Salivary glands can be stimulated by mechanical means, for example chewing hard food or chewing gum and chemical stimuli such as the taste of sour, sweet, salty, bitter and spicy (Subekti, 2014). This chemical stimulus can be obtained from the consumption of coffee and tea, as coffee and tea have a bitter taste that can stimulate secretion salivary changes.

One of the benefits or the benefits of tea to the $\mathrm{pH}$ of saliva is the ability to prevent cavities because in tea is found an active fluoride substance to protect teeth from plaque, to prevent the growth of dental caries and to strengthen the tooth (Rossi, 2010).

Preliminary studies conducted on Indonesian women community known as Pemberdayaan Kesejahteraan Keluarga (PKK) or (Indonesian Empowerment Family Welfare) in district of Genuk, Semarang, Indonesia, revealed that most women usually consumes black tea in the morning and sometimes also consume black coffee. These women seem to experience the tooth decay. As such, the researchers are interested in analyzing the effect of black coffee and tea consumption on the $\mathrm{pH}$ of saliva in mothers consuming these beverages.

\section{Materials AND Methods}

The method used in the study is a quasiexperiment. The design of this study was pre- 
test and post-test where the observation is done twice: before treatment and after treatment (Notoatmodjo, 2012). Two groups of samples were measured the $\mathrm{pH}$ of saliva prior to the study (before consumption of black coffee and black tea) and made final observations to measure the state of the $\mathrm{pH}$ of saliva after treatment.

This study uses technique total sampling those samples taken in this study is the overall members of Indonesian Empowerment Family Welfare in district of Genuk, Semarang, Indonesia, with the number of 40 people divided into two groups: those who consume black coffee and those who consume black tea consumption. Data were presented in descriptively to describe the results of studies using percentages presented in tables and graphs then a conclusion was drawn.

\section{RESULTS AND DISCUSSIONS}

\subsection{Result}

The first group was about 20 people with the treatment of black coffee consumption and the second group of 20 people with the treatment of black tea consumption. The results after the study are presented in the following tables.

Table1. Distribution of the frequency of saliva $\mathrm{pH}$ before and after consumption of black coffee

\begin{tabular}{|c|c|c|c|c|}
\hline $\begin{array}{c}\text { Ph } \\
\text { saliva } \\
\text { criteria }\end{array}$ & \multicolumn{2}{|c|}{$\begin{array}{c}\text { Before black } \\
\text { coffee } \\
\text { consumption }\end{array}$} & \multicolumn{2}{c|}{$\begin{array}{c}\text { After black } \\
\text { coffee } \\
\text { consumption }\end{array}$} \\
\cline { 2 - 5 } & $\mathrm{n}$ & $\mathrm{f}(\%)$ & $\mathrm{n}$ & $\mathrm{f}(\%)$ \\
\hline Acid & 6 & 30 & 11 & 55 \\
\hline Neutral & 4 & 20 & 2 & 10 \\
\hline base & 10 & 50 & 7 & 35 \\
\hline Total & 20 & 100 & 20 & 100 \\
\hline
\end{tabular}

Table 1 displays that there is a difference in $p H$ saliva before and after consumption of black coffee. The state of salivary $p H$ before black coffee consumption mostly with base criteria that is equal to $50 \%$ (10 people) and the lowest state with a neutral criterion which is $20 \%$ (4). While on treatment after his condition turned black coffee consumption that salivary $\mathrm{pH}$ acid criteria of $55 \%$ (11 people), alkaline criteria decreased to $35 \%$ (7) and lowest for a neutral criterion of $10 \%$ (2).

Table2. Distribution of the frequency of saliva $\mathrm{pH}$ on the treatment before and after consumption of black tea

\begin{tabular}{|c|c|c|c|c|}
\hline $\begin{array}{c}\text { Ph } \\
\text { saliva } \\
\text { criteria }\end{array}$ & \multicolumn{2}{|c|}{$\begin{array}{c}\text { Before } \\
\text { consumption of } \\
\text { black tea }\end{array}$} & \multicolumn{2}{|c|}{$\begin{array}{c}\text { After } \\
\text { consumption of } \\
\text { tea black }\end{array}$} \\
\hline & $\mathrm{n}$ & $\mathrm{f}(\%)$ & $\mathrm{n}$ & $\mathrm{f}(\%)$ \\
\hline Acid & 8 & 40 & 4 & 20 \\
\hline
\end{tabular}

\begin{tabular}{|c|c|c|c|c|}
\hline Neutral & 7 & 35 & 4 & 20 \\
\hline Bases & 5 & 25 & 12 & 60 \\
\hline & 20 & 100 & 20 & 100 \\
\hline
\end{tabular}

Table 2 shows that there is a difference in the $\mathrm{pH}$ of saliva before and after consumption of black tea. The state of salivary $\mathrm{pH}$ before black tea consumption is large with the acid criterion is $40 \%$ (8), and the lowest state is the base criterion of $25 \%$ (5). On treatment after the consumption of black tea, circumstances change that salivary $\mathrm{pH}$ criterion base was increased to $60 \%$ (12 people), the criteria of acid fell to $20 \%$ (4) and the criteria of the neutral is equal to the number of acid criteria in the amount of $20 \%$ (4).

Table3. Difference in average values saliva $\mathrm{pH}$ After Black Coffee and Black Tea Consumption

\begin{tabular}{|c|c|c|c|}
\hline $\begin{array}{c}\text { Treatment } \\
\text { Group }\end{array}$ & $\begin{array}{c}p H \\
\text { Before }\end{array}$ & $\begin{array}{c}p H \\
\text { After }\end{array}$ & Difference \\
\hline Black Coffee & 7.2 & 6.8 & 0.4 \\
\hline Black Tea & 6.9 & 7.2 & 0.3 \\
\hline
\end{tabular}

Table 3 indicates that there is a difference in the $\mathrm{pH}$ of saliva before and after black coffee and black tea consumption. The $\mathrm{pH}$ value of saliva before and after consumption of black coffee tends to fall from 7.2 to 6.8 with a difference of 0.4 and categorized in a state with acid criteria. As for the value of the $\mathrm{pH}$ of saliva on treatment before and after consumption of black tea tends to rise from 6.9 to 7.2 with a difference of 0.3 and categorized in a state with base criteria. Both of these treatments have differences that influence the $\mathrm{pH}$ of saliva where after the black coffee consumption could potentially reduce the $\mathrm{pH}$ of saliva, while after consumption of black tea has the potential to raise the $\mathrm{pH}$ of saliva.

\subsection{Discussion}

The results of treatment of black coffee consumption obtained largely salivary $\mathrm{pH}$ before the consumption of black coffee tend to base criteria, namely by $50 \%$, after being given the treatment of black coffee consumption showed $\mathrm{pH}$ the highest with acid criteria of 55\% and $\mathrm{pH}$ the lowest neutral criteria of $10 \%$. Black coffee consumption could potentially reduce the $\mathrm{pH}$ of saliva because coffee contains a high carbohydrate, sucrose, and monoxide. Streptococcus mutant bacteria are capable of lowering the $\mathrm{pH}$ of saliva by the fermentation of carbohydrates into acids in the mouth. In accordance with the opinion of Andriany, et al (2012) which states that the carbohydrates are fermented by the bacteria present in the mouth and form acids, which can lower the $\mathrm{pH}$ of saliva. This situation is a critical $\mathrm{pH}$ circumstances that can lead to tooth decay. The 
tendency of black coffee consumption influences the $\mathrm{pH}$ of as after consumption of black coffee, the salivary $\mathrm{pH}$ tends to fall into the criteria of acid.

The treatment of black tea consumption results obtained that in most circumstances salivary $\mathrm{pH}$ before black tea consumption tends to acid criteria is $40 \%$. Once treated with the highest consumption of black tea, the number is increased by $60 \%$ with base criteria, and then the criteria of neutral and acidic are equally by $20 \%$. The results indicate that black tea could potentially increase the $\mathrm{pH}$ of saliva because usually when consumed, black tea tasted a little bitter and bitter taste can suppress changes. Subekti (2014) states that the change in the $\mathrm{pH}$ of saliva is affected by chemical stimuli, namely with a bitter taste. These stimuli can affect secretion rate of saliva so that the volume of saliva is to rise and affect the $\mathrm{pH}$ to be increased. Substances can stimulate secretion are the chemical stimuli such as sweet, salty, bitter, spicy tastes. Based on the above presentation there is a tendency of black tea consumption influences $\mathrm{pH}$ of saliva where the $\mathrm{pH}$ tends to increase into a base criterion.

Differences changes of saliva in both treatments can be caused by a diet rich in carbohydrates and stimulating secretion rate of saliva can directly influence the changes in the degree of acid $(\mathrm{pH})$ in the mouth. In accordance with Sari (2015), the degree of acid (pH) is affected by several changes that include diet, day and night rhythm, stimulating the secretion rate and duration of stimulation. The acidity of saliva also affects the incidence of dental cavities or caries. The more acidic, the easier the occurrence of caries. According to Rukmana (2014), caffeine content in coffee black have anti-bacterial that can keep the bacteria causing tooth decay, and black tea is also beneficial to inhibit the growth of plaque on the teeth to be effective in preventing tooth decay (caries).

\section{CONCLUSION}

There is a tendency of influence between consumption of black coffee and black tea on the $\mathrm{pH}$ of saliva. Black coffee consumption tends to lower the $\mathrm{pH}$ of saliva, whereas black tea consumption tends to raise the $\mathrm{pH}$ of saliva.

\section{REFERENCES}

[1] Andriany, P., Hakim, R. F., Mahlianur, 2012, Pengaruh Konsumsi Kopi Ulee Kareng (Arabika) terhadap pH Saliva pada Usia Dewasa Muda, Jurnal Dentika Fakultas Kedokteran Gigi : Universitas Syiah Kuala, Desember 2012, Volume 17 (2

[2] Imran, H., Nurdin., Nasri, 2016, Pengaruh Konsumsi Kopi terhadap Penurunan pH Saliva pada Usia Dewasa, Jurusan Keperawatan Gigi : Politeknik Kesehatan Kemenkes Aceh, Juli 2016, Volume VII (3) ISSN 2502-7778

[3] Koerniati, I., 2006, Perkembangan Perawatan Gigi Masa Depan, Andalas University Press, Sumatra Barat.

[4] Notoadmodjo, I., T., 2012, Metodologi Penelitian Kesehatan, Rineka Cipta, Jakarta.

[5] Pratiwi, D., 2007, Gigi Sehat Merawat Gigi Sehari-hari, Buku Kompas : Jakarta. Rossi, 2010, 1001 Teh dari Asal-usul, Khasiat, hingga Racikan Teh, CV. Andi Offset: Yogyakarta. (Hal 13-15, 100-124)

[6] Rukmana, R., 2014, Untung Selangit dari Agribisnis Kopi, Lily Publisher: Yogyakarta.

[7] Sari, S. D. W, 2015, Perbandingan Sebelum dan Sesudah Menggunakan Batang Siwak terhadap pH saliva pada siswa MTS Kelas VII A Santri Pondok Pesantren Mathlaul Khaer Cinta pada Kecamatan Cibeureum Kota Tasikmalaya, Jurusan Keperawatan Gigi : Politeknik Kesehatan Tasikmalaya, Juli 2015

[8] Subekti, A., Ika, M., Hermien, R, 2014, Pengaruh Berkumur Rebusan Daun Mint (Mentha Piperita) terhadap Perubahan $\mathrm{pH}$ saliva, Jurusan Keperawatan Gigi : Politeknik Kesehtan Semarang, Desember 2014.

[9] Rossi, S., Marciello, M., Bonferoni, M. C., Ferrari, F., Sandri, G., Dacarro, C., ... \& Caramella, C. (2010). Thermally sensitive gels based on chitosan derivatives for the treatment of oral mucositis. European Journal of Pharmaceutics and Biopharmaceutics, 74(2), 248-254.

Citation: Erni Mardiati, Endah Aryati, Irmanita Wiradona, Bedjo Santoso. The Effect of Black Coffee and Tea Consumption to Saliva Degree of Acidity in Preventing Tooth Decay. ARC Journal of Dental science. 2017; 2(3): 1-3. doi:dx.doi.org/10.20431/2456-0030.0203003.

Copyright: (C) 2017 Authors. This is an open-access article distributed under the terms of the Creative Commons Attribution License, which permits unrestricted use, distribution, and reproduction in any medium, provided the original author and source are credited. 